\title{
Effective Management Tools for Solving the Problem of Poverty in Relation to Food Waste in Context of Integrated Management of Energy
}

\author{
Bohuslava Mihalčová ${ }^{1, *}$, Antonín Korauš ${ }^{2, *}$, Olha Prokopenko ${ }^{3} ®$, Jozefína Hvastová ${ }^{4}$, Magdaléna Freňáková ${ }^{5}$, \\ Peter Gallo ${ }^{6}{ }^{\oplus}$ and Beáta Balogová ${ }^{6}$
}

1 Department of Management, Faculty of Business Economy, University of Economics in Bratislava, 85235 Košice, Slovakia

2 Academy of the Police Force in Bratislava, Sklabinská 1, 83517 Bratislava, Slovakia

3 Economics Department, Collegium Mazovia Innovative University, 08-119 Siedlce, Poland; prokopenko.olha.w@gmail.com

4 Department of Economics, Faculty of Business Economy, University of Economics in Bratislava, 85235 Košice, Slovakia; jozefina.hvastova@euba.sk

5 Department of Corporate Financial Management, Faculty of Business Economy, University of Economics in Bratislava, 85235 Košice, Slovakia; magdalena.frenakova@euba.sk

6 Institute of Educology and Social Work, Faculty of Arts, University of Prešov in Prešov, 08001 Prešov, Slovakia; peter.gallo.1@unipo.sk (P.G.); beata.balogova@unipo.sk (B.B.)

Citation: Mihalčová, B.; Korauš, A.; Prokopenko, O.; Hvastová, J.; Freňáková, M.; Gallo, P.; Balogová, B Effective Management Tools for Solving the Problem of Poverty in Relation to Food Waste in Context of Integrated Management of Energy. Energies 2021, 14, 4245. https:// doi.org/10.3390/en14144245

Academic Editors: Aleksy Kwilinski, Aleksandra Kuzior, Janusz Kotowicz and Oleksii Lyulyov

Received: 17 May 2021

Accepted: 29 June 2021

Published: 14 July 2021

Publisher's Note: MDPI stays neutral with regard to jurisdictional claims in published maps and institutional affiliations.

Copyright: (c) 2021 by the authors. Licensee MDPI, Basel, Switzerland. This article is an open access article distributed under the terms and conditions of the Creative Commons Attribution (CC BY) license (https:/ / creativecommons.org/licenses/by/ $4.0 /)$.
* Correspondence: bohuslava.mihalcova@euba.sk (B.M.); antonin.koraus@akademiapz.sk or akoraus@gmail.com (A.K.)

Abstract: Globally, millions of people suffer from poverty. This paper discusses the problem of poverty especially in relation to food waste. The prevention of food waste can also contribute to global poverty reduction, and the reduction of food waste is a tool for sustainable growth and competitiveness. At present, the number of people at risk of poverty and the amount of food waste are increasing at unsustainable rates. An integrated and efficient tool for the management of food, energy, and water (FEW) resources to improve FEW security via an interdisciplinary approach could help address several of the most significant global challenges, such as climate change, and economic, environmental, and social security. The aim of this study was to examine the relationship between the existence of poverty and the treatment of food for sustainable growth. The analysis focused on the EU countries and the main data source was the Eurostat database. Households generally create the largest proportion of food waste. Pareto analysis shows that in households, food and non-alcoholic beverages are among the first group of expenses, and in the EU countries they represent approximately $12 \%$ of the total expenses. Food and non-alcoholic beverages are a stable, unavoidable, and non-negligible element of total expenses. Paradoxically, enormous amounts of food are wasted. A relatively weak inversely proportional relationship between the amount of food waste per capita and the proportion of the population at risk of poverty among the total population of EU countries was identified through correlational analysis. A very weak relationship between the share of the population at risk of poverty in the total population and the amount of food waste per capita, excluding the population at risk of poverty, was also found.

Keywords: poverty reduction; food waste; managerial tools; sustainability; circular economy; the food-energy-water (FEW) nexus; management of energy

\section{Introduction}

The global economy appears likely to enter a recession, mainly due to the COVID-19 pandemic. Due to the pandemic, most countries are in lockdown; as a result, most food is currently being consumed within households. This situation is of benefit to farmers and retailers, who are attempting to respond effectively to changing demands and to meet consumers' needs [1]. 
To ensure sustainable growth on a national and global scale, it is essential to address the issue of poverty, which is often associated with food waste. We aimed to determine if food waste is really linked to poverty. Food waste is one of the most significant global challenges. In the context of sustainable development, meeting global food demand while reducing both pressure on food resources and greenhouse gas emissions is a major challenge for the future [2]. Reducing food waste is needed to achieve the goals of sustainable development. The differences between countries in their waste production, in relation to their nutritional resources used and environmental impact, are currently unknown [3,4].

The link between food, energy, and water (FEW) has been promoted in the context of improving food safety through an interdisciplinary approach that represents a compromise related to managing these resources. The discussion about these problems has recently spread rapidly in the professional community, and is related to the funding and outputs of research focused on this issue. An interdisciplinary approach to this issue is necessary because there are a number of different perspectives that represent different motivations and analytical methodologies [5]. The systems approach is now gaining critical awareness as a "buzzword", and the variation in the names previously used for systemic approaches in the literature has been mentioned by an increasing number of authors [6-9].

The combination of food, energy, and water is increasingly being discussed in the literature and legislative frameworks as an innovative means of addressing resources and development. In this context, a nexus approach has emerged to identify compromises in sectoral policies for water, energy, and food systems. Although FEW represents a conceptual approach that is suitable for the alliance between water, energy, and food, its use to support development remains limited [10]. To address the current health challenges, mixed methods and transdisciplinary approaches are used, which allow the involvement of all stakeholders who have decision-making powers [11-14]. Such an integrated management of energy, water, and food resources could contribute to solving major environmental problems such as climate change, in addition to financial, environmental and social problems [15-19].

Lack of awareness is a major obstacle to linking water, energy, and food targets. Numerous means exist to use the connection between these factors, e.g., heat recovery from wastewater, use of food waste and subsequent reuse, and electricity generation. To date, policies are only effective at the national level; however, policy makers in the EU are currently working together and there are positive cases of such cooperation $[20,21]$.

The problem of poverty cannot be viewed narrowly, and must be broadly understood as a problem of inequality and inaccessibility of social goods (employment, education, housing, health care, and even participation in society). In connection with demographic change, globalization, industrialization, and food processing, the gap between rich and poor societies will become more pronounced, and problems related to the sustainability of food systems will arise [22-24].

Efforts to define a food-loss management strategy are gaining momentum. Most strategies have focused on mass and energy recovery through centralized recovery models of food loss [25-27].

Poverty is both an absolute and a relative phenomenon. Absolute poverty is understood to be physical (bare) survival. This means that there is a lack of resources available to meet basic or life-enabling needs [28]. This concept more closely applies to poor developing countries. In developed countries, the concept of relative poverty, which is typically derived from a certain (usually average) standard of living, is used. According to the EU methodology, the poverty risk threshold represents $60 \%$ of the national balanced median income [29]. In practice, this means that although a person is able to satisfy their basic life needs, which are common in a given society, they may be excluded from society, have limited social relationships, and suffer from social isolation. This relates to the notion of social exclusion, which is directly related to poverty [30]. Poverty reduction encompasses more than a single goal because there is no universal means of reducing poverty that affects people in different places and under different circumstances at different times. 
It is therefore evident that there are many approaches to defining poverty, and that it is not possible to develop a generally accepted definition. However, most of the commonly used definitions of poverty have two common elements, namely, the welfare indicator and the setting of the poverty line. Frequently used welfare indicators include income, consumption and food consumption, the share of food expenditure in total expenditure, caloric intake, health service consumption, and fulfillment of basic needs. The poverty line can be seen as a dividing point that divides individuals into the poor (the individual's wellbeing does not exceed the poverty line) and the not poor (the poverty line is exceeded) [31].

Previous authors [32-36] have stated that the feeling of poverty affects the perception of well-being and can contribute to the reduction of consumption regardless of the actual household income. Uncertainty about future household income can reduce current consumption levels and increase the feeling of poverty in risk-affected households, which are characterized by precarious employment situations and frequent changes.

Considering the facts mentioned above, we approached this phenomenon via managerial tools and statistically evaluated the collected data. We primarily focused on the problem of food waste as one of the welfare indicators. The main goal of the research was to examine the relationship between the existence of poverty and food management using Pareto and correlation analyses. The choice of these tools is explained in the methodological section of the paper. We formulated the following research questions: (RQ1) How important is food expenditure in household expenditure? (RQ2) Is food waste in countries related to the number of people at risk of poverty? Our aim was also to examine the relationship between the percentage of the total population at risk of poverty and the amount of food waste per capita, excluding the population at risk of poverty [37,38].

Relatively little research has been undertaken regarding current food waste. The aim of our study was to contribute to the expansion of this issue, because it has become increasingly relevant, particularly during the current pandemic period. Consumers have realized the importance of food security and the prevention of food waste. Thus, the present study represents an opportunity to fill gaps in the research related to food waste and the overall food security of the population.

This article is divided into sections. The first section consists of a literature search, which we undertook using the available professional publications and studies carried out by domestic and foreign authors. In this part of the study, we relied mainly on indexed citation databases.

In the second section, we describe the methodology and methods used to examine the research related to food waste.

The third section of this article presents the results of our research and a related discussion. The research questions established in this study were statistically verified, and the obtained results are compared with those of existing studies.

In the final section, we present a summary of our research, limitations of the study research, and our future research interests.

\section{Theoretical Background}

The author of [39] states that poverty is understood to be a situation in which a person's basic functioning is affected by their difficult circumstances, and their opportunities for a better life are considerably limited. Poverty and social exclusion are closely linked, and affect the social relationships of the individual within society. Poverty is defined in economic and material terms, and is a multidimensional construct in relation to the different characteristics of the poor [40]. The Economic Cooperation and Development Committee (OECD) has issued guidelines on poverty reduction and established a Development Assistance Committee (DAC) [41]. The document has been periodically updated to reflect changing factors, and the current DAC document reflects the problems caused by the current pandemic [42]. This committee defines poverty as a situation without economic, human, protective, political and socio-cultural capacities.

Poverty varies depending on the country, region, or group of people being compared. 
Poverty is one of the most significant current global challenges, and addressing this problem is an important consideration in several strategic documents. Bringing an end to poverty is the first topic of the UN 2030 Agenda for Sustainable Development, and the fight against poverty and social exclusion is one of the European Union's main objectives, as expressed in the Europe 2020 strategy [43].

Food waste is a global problem. Although most consumers are opposed to food waste, significant food waste takes place [44,45]. The authors of [46] focus on the factors that prevent waste. Empirical data reveal factors that have a significant impact on food and waste prevention practices. The first, "individual/interpersonal interest", has a strong relationship with these routines, whereas the second, "global interest", has no significant relationship with them. For policy makers and managers seeking to reduce food waste at the household level, this research provides recommendations that influence food waste behavior through individual and interpersonal factors (such as economic problems, the importance of food, and education in food areas).

The author of [47] states that food waste threatens food security, and that research programs must be established by researchers from developed and developing countries to help contribute to food recycling and food security.

The attitudes and behavior of the population towards food waste have changed as a result of the COVID-19 pandemic. Residents are trying to use food more efficiently due to the pandemic, which may occur again [48].

In an existing study [49], the authors conducted research on food waste. Although the results showed an increase in overall food purchases and a slight decrease in the generation of food waste due to the pandemic, the links between these results and basic behavior were complex. For example, reduced food waste from households was significantly correlated with an increase in behaviors such as meal planning, food preservation, and the use of food scraps and storage-stable products. Conversely, self-sufficiency behavior, including bulk purchasing and stockpiling, was significantly correlated with increased food purchases, which in turn led to increased waste.

Food waste is a significant problem for humanity. Approximately one-third of all food produced for human consumption is lost. Food waste can not only contaminate large quantities of fresh water and soil, and require a large amount of labor, but it is also detrimental to the environment and the climate. The greatest impact of food waste in developed countries is on infrastructure; however, in developing countries, this impact is on consumer levels. Reducing food waste can reduce global greenhouse gas emissions [50,51].

Food waste is one of the most significant global environmental problems. Waste and losses are generated at each stage of the food supply chain. Several waste management methods have been developed for the disposal of food waste, but these involve a number of challenges, such as high costs, the formation of toxic by-products, and environmental pollution. The problem of food waste has recently attracted increased interest, leading to the development of new products as potentially sustainable and environmentally friendly solutions [52-54].

The objective concept of poverty seeks to define poverty through factors that do not depend on the personal opinion and feelings of the individual. It is based on analyses of socio-economic information relating to households or sets of households [55]. Food systems, and their resources, structures, and policies that enable food to travel from farms to consumers, have been destroyed and will take a long time to recover [56].

\section{Poverty in the European Union}

In the EU, the issue of poverty also encompasses problems related to inequality of people and their access to various social goods [57,58]. In the European Union, people whose equivalent disposable income is below $60 \%$ of the national median equivalent income, or who are materially disadvantaged, are considered to have severely reduced living conditions and are at risk of material deprivation. As a result, they cannot afford at least four of nine items-payment of rent, mortgage, or electricity expenses; maintenance of 
household warmth; unexpected expenses; consumption of meat, fish, or equivalent proteins every other day; weekly vacation away from home; car ownership; washing machine; phone; or color television. The final group at risk of poverty comprises households with very low labor intensity. Information published by Eurostat showed that in 2017, 22.4\% of the population, or 112.974 million people, were at risk of poverty or social exclusion in the EU. The level of risk of this poverty varied between EU countries, ranging from $12.2 \%$ (Czech Republic) to $38.9 \%$ (Bulgaria). In Slovakia, this rate was 16.3\%, which was among the lower-ranked countries. The manifestations of poverty that affect people, particularly in developed countries such as those of the EU, are manifold and largely related to social exclusion.

As stated by [59], poverty is no longer a problem of only Third World countries because all countries can admit to the existence of poor individuals and families. That said, in Slovakia, the home nation of the authors, the concept of poverty does not have a comprehensive legal definition. Within the consciousness of society, terms such as socially disadvantaged individuals, low-income households, and people living in material deprivation, can be considered to be synonyms for populations affected by poverty.

As part of the analysis of poverty in Slovakia, the authors present data from the Statistical Office of the Slovak Republic. The annual poverty line in Slovakia in 2017, which was set by the EU at $60 \%$ of the median national equivalent disposable income, was calculated to be EUR 4310 for a one-member household and EUR 9051 for a household with two adults and two children. Within the household category, the most at-risk are one-member households with a person under 65 years old without dependent children (25.8\%) and single-parent households with at least one dependent child (37.3\%). According to the status of economic activity, the risk of poverty in non-working people is up to 2.6 times higher than that of working people. Poverty, as mentioned above, has entered the official documents and guidelines of the social policies of the EU Member States as an object of intervention. Poverty can be examined from several perspectives. One of the challenges is the view of poverty in connection with food waste. The OECD has issued a waste hierarchy that provides guidance on how to reduce, recycle, and reuse foods that have fallen out of the food chain [60].

\section{Materials and Methods}

Food waste occurs at every stage of the food supply chain. This is not only confined to food that is not sold by shops, consumed by restaurants, or sold by producers (for example, due to poor storage). The most significant problem does not relate to retail chains or catering establishments, because households make the greatest contribution to the production of food waste. This remains a global problem, for which a solution is increasingly needed. Therefore, the main goal of the research was to examine, using managerial tools, the relationship between the existence of poverty and food waste.

Based on this, we formulated the following research questions:

RQ1: How important is food expenditure in household expenditure?

$\mathrm{RQ2}$ : Is food waste in countries related to the number of people at risk of poverty?

To elaborate the subject matter and determine answers to these research questions, we used general methods (analysis, synthesis, and comparison), and the managerial tools and methods of one-dimensional and two-dimensional descriptive statistics.

As a managerial tool, Pareto analysis can be used to analyze gaps and potential opportunities for poverty reduction. A Pareto diagram is a method applied to one-dimensional descriptive statistics in the form of a bar graph to express the frequency of discrete nonnumeric data. It allows the impact of individual input factors on the monitored parameter to be determined, and helps efforts for improvement to be targeted appropriately. We analyzed household expenditure and identified the groups of products or services that account for the largest share of this expenditure. This analysis drew attention to a major current phenomenon - food waste as a causes of poverty - and we examined whether food expenditure is one of the major groups of total household expenditure. We used the Pareto 
80:20 principle to divide household expenditure into groups. The Pareto diagram was supplemented by the Lorenz cumulative curve. In the current study, this curve expresses the cumulative significance of household expenditure up to $80 \%$, and we considered all categories listed to the left of this point to be significant. The main data source was Eurostat data on household expenditure in the countries of the EU in 2017.

Correlation analysis is a method of two-dimensional descriptive statistics that is used to examine the relationship between two variables. The strength or tightness of the linear dependence of two variables is represented by the correlation coefficient. The result is a value within the interval $\langle-1,1\rangle$, where the sign indicates the direction of the dependence (a positive sign represents a direct dependence and a negative sign represents an indirect dependence). The dependence is considered to be stronger the closer the obtained absolute value is to 1 . Based on the Pearson correlation coefficient, we identified the degree of dependence of the population at risk of poverty on the amount of food waste in the EU, assuming that the values representing the number of people at risk of poverty and the amount of food waste come from a normal probability distribution. First, we examined the dependence of the population at risk of poverty on the total amount of food waste. Results of greater informative value were provided by the study of the dependence between the amount of food waste per capita and the percentage of the population at risk of poverty in the total population of individual countries. To illustrate the situation, we also examined the relationship between the percentage of the population at risk of poverty in the total population and the amount of food waste per capita, excluding the population at risk of poverty. As a first step in determining the dependence between the two rows of values, we used a scatterplot, and we interpolated this dependence with a straight line. The data for the calculation of dependencies were taken from Eurostat databases. These data present the state of food waste in 2012, when the study on the amount of food waste was undertaken for the first time. This study collected and, for the first time, provided comprehensive data on the amount of food waste in Europe. The values presenting the number of people at risk of poverty in these countries were also taken from 2012 for the sake of comparability.

\section{Results and Discussion}

This section includes an analysis aimed at finding answers to research questions resulting from the stated objective. Briefly, RQ1 refers to the determination of the importance of food expenditure in total household expenditure. RQ2 refers to the determination of the relationship between food waste and the number of people at risk of poverty.

\subsection{Pareto Analysis}

Food waste is closely related to the amount of food that individual entities purchase or produce. Because households account for the largest percentage of total food waste we monitored the expenditure of this particular entity with the intention of identifying the share of expenditure on food and non-alcoholic beverages in total expenditure. Household expenditure is significantly influenced by state policy. The share of expenditure on nonessential goods and services also illustrates the overall standard of living in society. Table 1 shows the purposes of spending by European households in 2017. The total household expenditure in 2017, which amounted to EUR 8,362,260.4, was used for various groups of goods or services. 
Table 1. Household expenditure in the countries of the EU in 2017. Source: created by authors according to data from [61].

\begin{tabular}{|c|c|c|c|c|c|}
\hline Item & $\begin{array}{l}\text { Percentage of } \\
\text { Total Expenditure }\end{array}$ & $\begin{array}{l}\text { Cumulative } \\
\text { Sum of Volume }\end{array}$ & $\begin{array}{l}\text { Expenditure } \\
\text { Group }\end{array}$ & $\begin{array}{l}\text { Percentage of the } \\
\text { Group in the } \\
\text { Number of Items }\end{array}$ & $\begin{array}{l}\text { Percentage of the } \\
\text { Group in } \\
\text { Expenditure }\end{array}$ \\
\hline $\begin{array}{l}\text { Housing, water, electricity, gas and } \\
\text { other fuels }\end{array}$ & $24.2 \%$ & $24.2 \%$ & 1 & \multirow{6}{*}{$50 \%$} & \multirow{6}{*}{$50 \%$} \\
\hline Transport & $13.0 \%$ & $37.2 \%$ & 1 & & \\
\hline Food and non-alcoholic beverages & $12.2 \%$ & $49.4 \%$ & 1 & & \\
\hline Miscellaneous goods and services & $11.4 \%$ & $60.8 \%$ & 1 & & \\
\hline Restaurants and hotels & $8.8 \%$ & $69.6 \%$ & 1 & & \\
\hline Recreation and culture & $8.5 \%$ & $78.1 \%$ & 1 & & \\
\hline $\begin{array}{l}\text { Furnishings, household equipment } \\
\text { and routine household maintenance }\end{array}$ & $5.5 \%$ & $83.6 \%$ & 2 & \multirow{5}{*}{$50 \%$} & \multirow{5}{*}{$50 \%$} \\
\hline Clothing and footwear & $4.9 \%$ & $88.5 \%$ & 2 & & \\
\hline $\begin{array}{l}\text { Health } \\
\text { Alcoholic beverages, tobacco and } \\
\text { narcotics }\end{array}$ & $\begin{array}{l}4.0 \% \\
3.8 \%\end{array}$ & $\begin{array}{l}92.5 \% \\
96.3 \%\end{array}$ & $\begin{array}{l}2 \\
2\end{array}$ & & \\
\hline Communications & $2.5 \%$ & $98.8 \%$ & 2 & & \\
\hline Education & $1.1 \%$ & $100 \%$ & 2 & & \\
\hline Total & $100 \%$ & - & - & $100 \%$ & $100 \%$ \\
\hline
\end{tabular}

Table 1 shows that, for 2017, the first group of expenditure consists of housing costs, transport, food and non-alcoholic beverages, miscellaneous goods and services, restaurants and hotels, and recreation and culture; this group represents $50 \%$ of all items, but represents $78.1 \%$ in terms of the total amount of expenditure.

Based on Figure 1, 78.10\% of household expenditure is caused by only $50 \%$ of items that relate to this expenditure. In our case, in particular, $78.10 \%$ of the household expenditure arises as a result of expenditure on housing, water, electricity, gas and other fuels, transport, food and non-alcoholic beverages, miscellaneous goods and services, restaurants and hotels, and recreation and culture.

The percentage of household expenditure does not change significantly from year to year. To illustrate this observation, in 2016, within the first group, household expenditure on housing, water, electricity, gas and other fuels represented $24.5 \%$, transport $12.9 \%$, food and non-alcoholic beverages $12.2 \%$, miscellaneous goods and services $11.5 \%$, restaurants and hotels $8.6 \%$, and recreation and culture $8.5 \%$. In total, the first group of items represented $78.2 \%$ of household expenditure [62].

In 2018, within the first group, household expenditure on housing, water, electricity, gas, and other fuels represented $24.0 \%$, transport $13.2 \%$, food and non-alcoholic beverages $12.1 \%$, miscellaneous goods and services $11.4 \%$, restaurants and hotels $8.7 \%$, and recreation and culture $9.1 \%$. In total, the first group of items in 2018 represented $78.5 \%$ of household expenditure [62].

When comparing the data for 2017 with the previous and subsequent years, it can be seen that these are comparable values both within individual items, and cumulatively. The first groups of expenditure items in the analyzed years represented $50 \%$ of all items and, in terms of total expenditure, represented $78.2 \%$ in $2016,78.1 \%$ in 2017 , and $78.5 \%$ in 2018 . Based on the results of individual years, we can state that a significant portion of European household expenditure is absorbed by only half of the group of items representing household expenditure.

As mentioned above, the first group, which affects a large proportion of household expenditure, also includes expenditure on food and non-alcoholic beverages. During the three years that were analyzed, household expenditure on food and non-alcoholic beverages in countries of the EU represented $12.2 \%$ of total household expenditure in $2017,12.2 \%$ in 2016 , and $12.1 \%$ in 2018 . However, the share of expenditure on food and 
non-alcoholic beverages varies from country to country. Figure 2 therefore presents the amount of expenditure that households in the individual European countries spend on food and non-alcoholic beverages. The data are presented as a percentage of expenditure within the total amount of household expenditure.

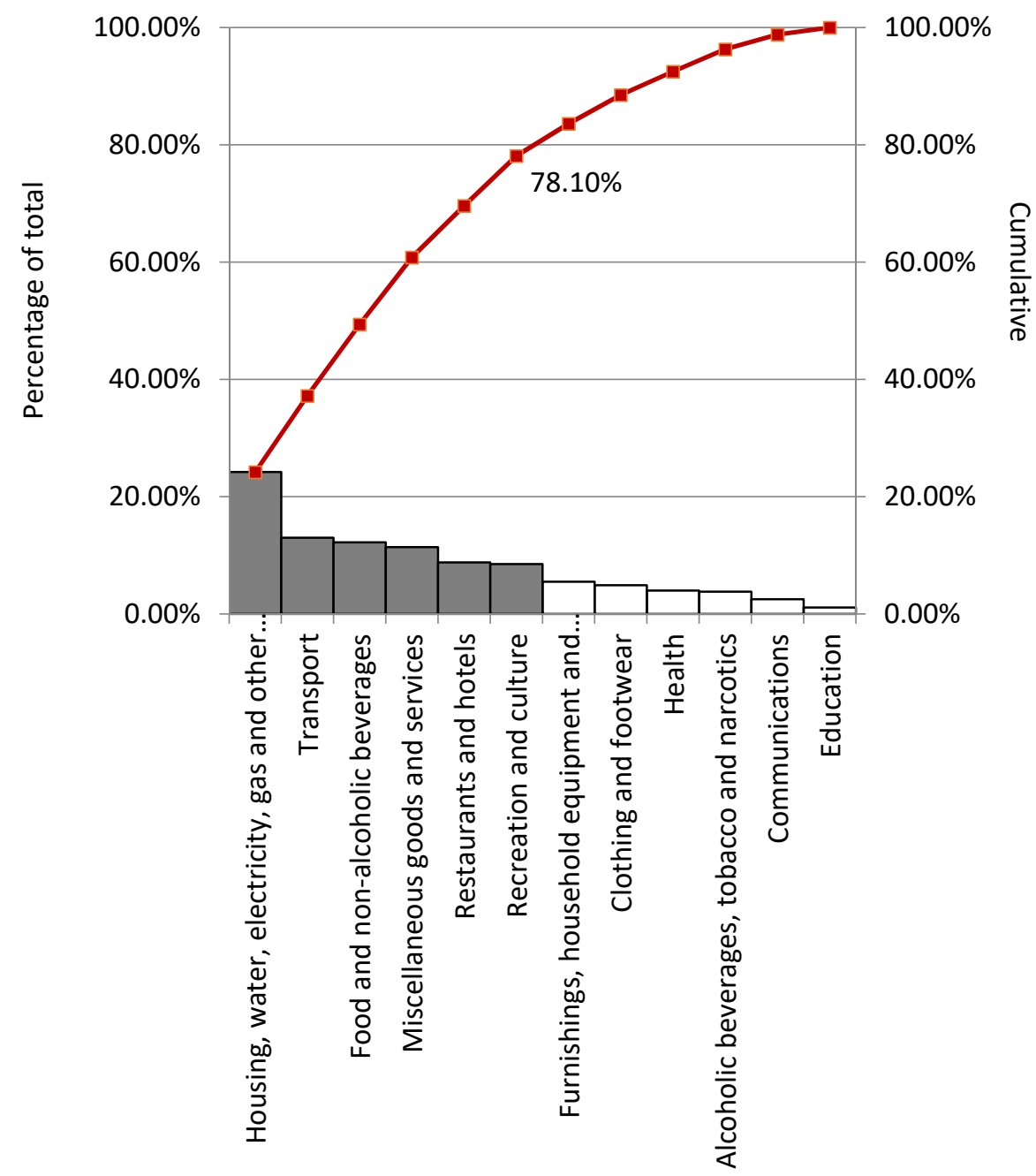

Figure 1. Structure of household expenditure in the countries of the EU in 2017. Source: created by authors according to data from [61].

It can be said that the structure of private consumption is one of the relative measures of a population's living standards. However, the largest share of household expenditure is represented by expenditure on food and non-alcoholic beverages, and this share is particularly high in the countries that are among the "poorer" countries within the EU. This is also indicated by a comparison of household expenditure on food and non-alcoholic beverages in the EU in 2016, 2017, and 2018 (Figure 2), from which it is clear that the highest shares of expenditure on food and non-alcoholic beverages during these years were observed in Romania, Lithuania, and Estonia. On the contrary, the lowest shares of expenditure on food and non-alcoholic beverages were observed in the United Kingdom, Luxembourg, and Austria.

Although the overall structure of household expenditure may change in individual periods and for various reasons, expenditure on food and non-alcoholic beverages represents the necessary expenditure of each household. Based on the facts above, it can be stated in relation to RQ1 that expenditure on food and non-alcoholic beverages is a stable item within the structure of household expenditure, and belongs to the group that significantly absorbs total household expenditure. 


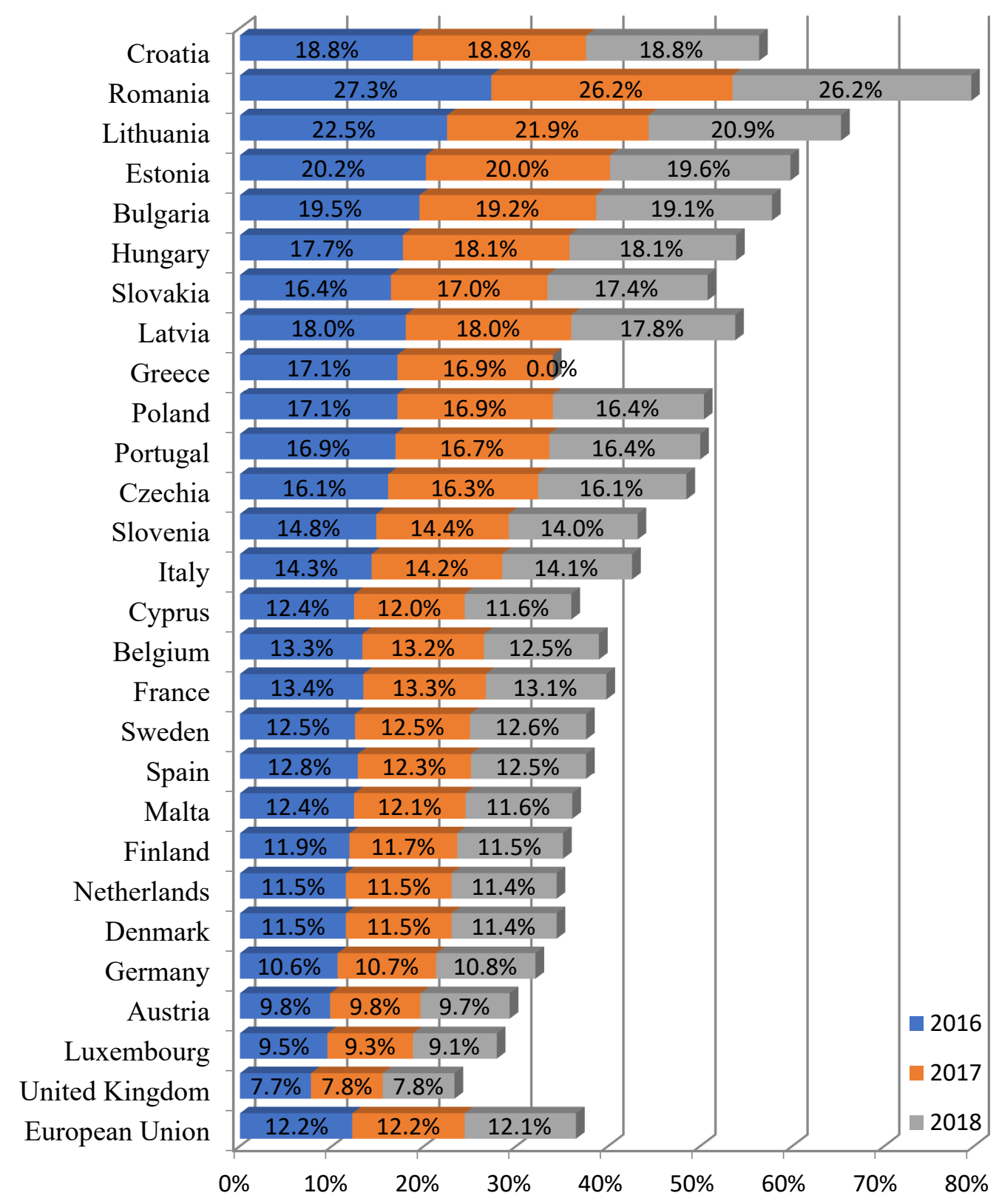

Note: Data for Ireland not available; data for Greece in 2018 not available

Figure 2. Household expenditure on food and non-alcoholic beverages in the EU in 2016, 2017, and 2018. Source: created by authors according to data from [62].

\subsection{Correlation Analysis}

Although food expenditure is a significant item of total expenditure, statistics indicate that enormous wastage of food takes place. However, this problem is not limited to households. The reasons for food waste vary according to the position in the supply chain. Business entities (producers, processors, retailers) make decisions to maximize profits, which often means wasting food, despite not aiming to generate food waste. By comparison, consumers have reasons other than achieving satisfaction, either in terms of meeting their nutritional needs or in other respects (quantity, surplus, price) [63]. 
Figure 3, therefore, shows the percentage share of individual actors in the supply chain (producers, processors, wholesale and retail, food services, households) in relation to the total amount of food waste in 2012. Further analysis is based on data for this year.

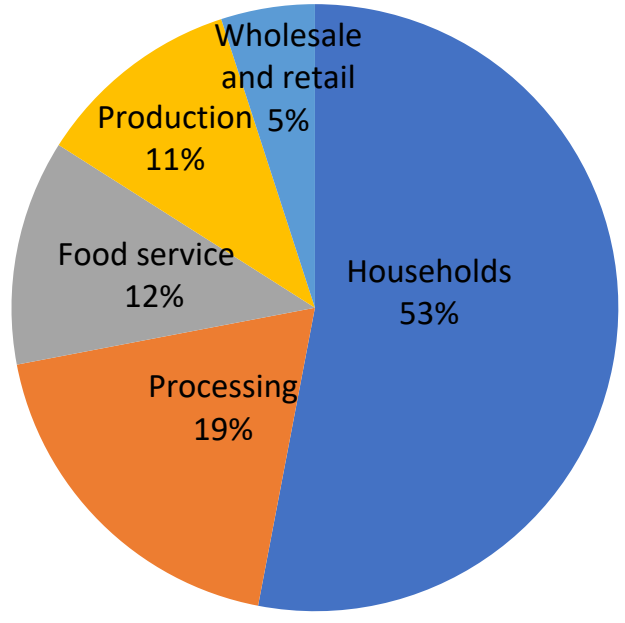

Figure 3. Food waste by individual actors in the supply chain in the countries of the EU in 2012. Source: created by authors according to data [62].

Food waste is also partially influenced by lifestyle. Current lifestyles remain a threat, thus providing justification for addressing the problem of food waste. Similarly, the conclusions of FUSIONS (2016) suggest that there is a relationship between food waste and poverty. In our study, we examined the relationship between the existence of the phenomenon of poverty and food waste. Table 2 presents the values of the variables that were used to examine the individual relationships.

Table 2. Poverty and food waste in the individual countries of the EU in 2012. Source: created by authors according to data from [61-65].

\begin{tabular}{ccccccc}
\hline Population & $\begin{array}{c}\text { Number of People } \\
\text { at Risk of Poverty } \\
\text { in Thousands }\end{array}$ & $\begin{array}{c}\text { Percentage of the } \\
\text { Population at } \\
\text { Risk of Poverty }\end{array}$ & $\begin{array}{c}\text { Total Food } \\
\text { Waste in } \\
\text { Thousands kg }\end{array}$ & $\begin{array}{c}\text { Food Waste in } \\
\text { Thousands kg } \\
\text { per Capita * }\end{array}$ & $\begin{array}{c}\text { Food Waste in Thousands kg } \\
\text { per Capita Except for People } \\
\text { at Risk of Poverty }\end{array}$ \\
\hline Belgium & 11.137974 & 2356 & 21.15 & 3.822600 & 0.34 & 0.44 \\
\hline Bulgaria & 7.284552 & 3621 & 49.71 & 769.335 & 0.11 & 0.21 \\
\hline $\begin{array}{c}\text { Czech } \\
\text { Republic }\end{array}$ & 10.516125 & 1580 & 15.02 & 851.310 & 0.08 & 0.10 \\
\hline Denmark & 5.602628 & 965 & 17.22 & 814.826 & 0.15 & 0.18 \\
\hline Germany & 80.523746 & 15.909 & 19.76 & 11.997480 & 0.15 & 0.19 \\
\hline Estonia & 1.320174 & 311 & 23.56 & 351.125 & 0.27 & 0.35 \\
\hline Ireland & 4.609779 & 1392 & 30.20 & 991.224 & 0.22 & 0.31 \\
\hline Greece & 11.003615 & 3795 & 34.49 & 887.200 & 0.08 & 0.12 \\
\hline Spain & 46.727890 & 12.628 & 27.02 & 6.320700 & 0.14 & 0.19 \\
\hline France & 65.600350 & 11.760 & 17.93 & 8.807400 & 0.13 & 0.16 \\
\hline Italy & 59.685227 & 17.975 & 30.12 & 10.630810 & 0.18 & 0.25 \\
\hline Cyprus & 865.878 & 234 & 27.02 & 281.878 & 0.33 & 0.45 \\
\hline Lithuania & 2.023825 & 975 & 48.18 & 357.476 & 0.18 & 0.34 \\
\hline Luxembourg & 537.039 & 95 & 17.69 & 92.915 & 0.17 & 0.13 \\
\hline Hungary & 9.908798 & 3272 & 33.02 & 1.757272 & 0.18 & 0.26 \\
\hline Malta & 422.509 & 94 & 22.25 & 31.733 & 0.08 & 0.10 \\
\hline
\end{tabular}


Table 2. Cont.

\begin{tabular}{ccccccc}
\hline & Population & $\begin{array}{c}\text { Number of People } \\
\text { at Risk of Poverty } \\
\text { in Thousands }\end{array}$ & $\begin{array}{c}\text { Percentage of the } \\
\text { Population at } \\
\text { Risk of Poverty }\end{array}$ & $\begin{array}{c}\text { Total Food } \\
\text { Waste in } \\
\text { Thousands kg }\end{array}$ & $\begin{array}{c}\text { Food Waste in } \\
\text { Thousands kg } \\
\text { per Capita * }\end{array}$ & $\begin{array}{c}\text { Food Waste in Thousands kg } \\
\text { per Capita Except for People } \\
\text { at Risk of Poverty * }\end{array}$ \\
\hline Netherlands & 16.779575 & 2492 & 14.85 & 9.050930 & 0.54 & 0.63 \\
\hline Austria & 8.451860 & 1542 & 18.24 & 1.738100 & 0.21 & 0.25 \\
\hline Poland & 38.062535 & 10.128 & 26.61 & 9.516910 & 0.25 & 0.34 \\
\hline Portugal & 10.487289 & 2667 & 25.43 & 1.391280 & 0.13 & 0.18 \\
\hline Romania & 20.020074 & 8673 & 43.32 & 1.527600 & 0.08 & 0.13 \\
\hline Slovenia & 2.058821 & 392 & 19.04 & 147.960 & 0.07 & 0.09 \\
\hline Slovakia & 5.410836 & 1109 & 20.50 & 599.844 & 0.11 & 0.14 \\
\hline Finland & 5.426674 & 916 & 16.88 & 1.202789 & 0.22 & 0.27 \\
\hline Sweden & 9.555893 & 1679 & 17.57 & 2.010396 & 0.21 & 0.26 \\
\hline United & 63.905342 & 15,099 & 23.63 & 15.033200 & 0.24 & 0.31 \\
\hline Kingdom & & 731 & 24.60 & 224.950 & 0.08 & 0.10 \\
\hline Latvia & 2.971905 & & Note: ${ }^{*}$ figures are rounded up. & & \\
\hline
\end{tabular}

Note: * figures are rounded up.

First, we assessed the dependence of the population at risk of poverty on the total amount of food waste, as shown in Figure 4. The value of the Pearson correlation coefficient in this case is 0.868 . On this basis, it can only be stated that, in countries with a higher number of people at risk of poverty, the amount of food waste is also growing. It should also be noted, however, that our analysis is based on absolute numbers (people at risk of poverty in thousands and food waste in thousands $\mathrm{kg}$ ) and, therefore, the high number of people at risk of poverty is naturally proportional to the population of each country (the greater the population, the greater the number of people at risk of poverty). Based on this finding, no conclusions can be drawn that would be relevant to tackling poverty.

Number of people at risk of poverty in thousands

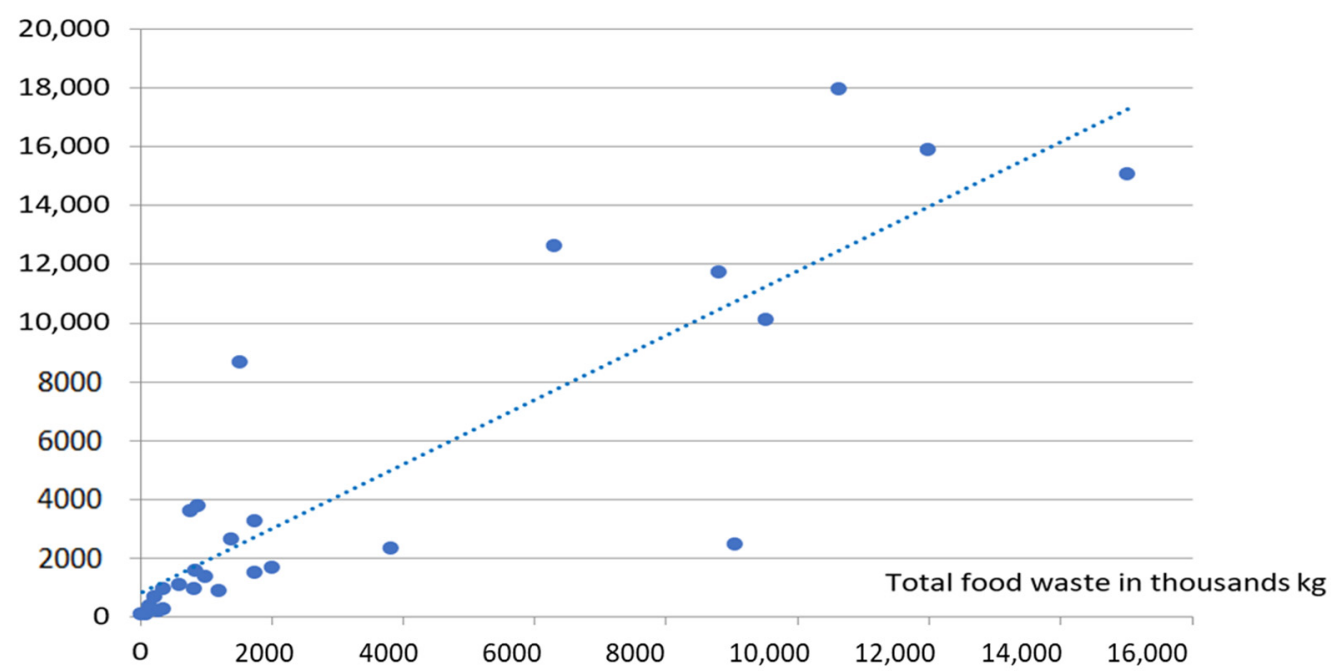

Figure 4. The relationship between the amount of food waste and the number of people at risk of poverty. Source: created by authors.

For a more objective analysis of the data, the amount of food waste per capita of each country was calculated. In addition, the share of the population at risk of poverty in the total population of the countries was expressed as a percentage. Subsequently, the relationship between these two variables was examined, as shown in Figure 5. The value 
of the Pearson correlation coefficient in this case is -0.252 . It is therefore an inversely proportional relationship, although with a relatively low correlation. We can state that in the countries with a larger amount of food waste per capita, there is a lower share of the population at risk of poverty in the total population. We can assume that a larger amount of food waste per capita (e.g., Belgium $343 \mathrm{~kg} /$ per capita and the Netherlands $539 \mathrm{~kg} / \mathrm{per}$ capita) is related to a higher standard of living in the country, and this is reflected in a lower share of the population at risk of poverty in the total population (e.g., Belgium $21.15 \%$ and the Netherlands $14.85 \%$, as can be seen in Table 2). On the contrary, less food waste per capita may be associated with a lower standard of living, which is reflected in a higher share of the total population at risk of poverty (e.g., Bulgaria with food waste $106 \mathrm{~kg} / \mathrm{per}$ capita and $49.71 \%$ of the population at risk of poverty, or Greece with food waste $81 \mathrm{~kg} / \mathrm{per}$ capita and $34.49 \%$ of the population at risk of poverty, as can be seen in Table 2).

Percentage of the population at risk of poverty

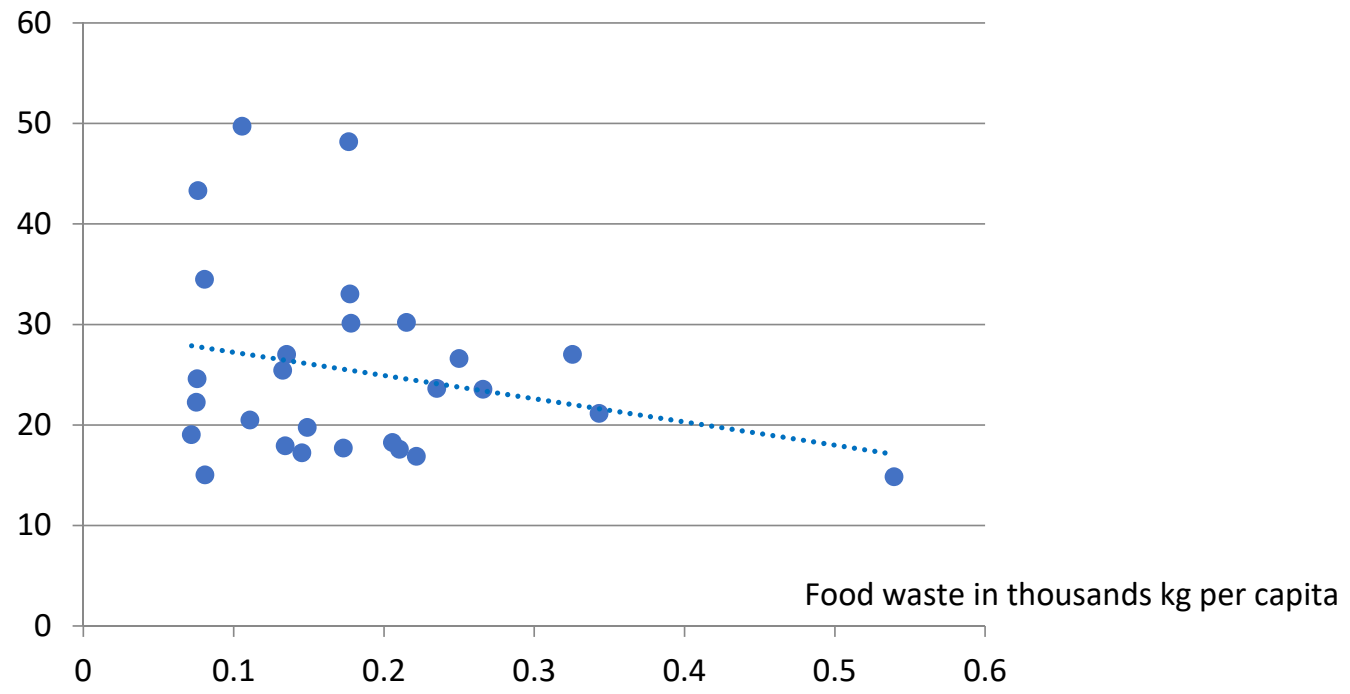

Figure 5. Relationship between the amount of food waste per capita and the percentage of the population at risk of poverty. Source: created by authors.

In the industrialized countries, significantly more food is wasted per capita than in developing countries. According to [66], food waste per capita in Europe and North America is $95-115 \mathrm{~kg} /$ year. In developing countries in sub-Saharan Africa and South-East Asia, food waste per capita is only 6-11 kg/year.

However, this is not the case in general. In our case, for example, countries exist that have a lower percentage of the population at risk of poverty and that are, simultaneously, among the countries with the lowest amounts of food waste per capita. These are the Czech Republic, with $81 \mathrm{~kg}$ of food waste per capita and $15.02 \%$ of the population at risk of poverty; Denmark, with $145 \mathrm{~kg}$ of food waste per capita and $17.22 \%$ of the population at risk of poverty; and Germany, with $149 \mathrm{~kg}$ of food waste per capita and $19.76 \%$ of the population at risk of poverty (as shown in Table 2). For this reason, the negative correlation coefficient is relatively low. This means that the phenomenon of poverty is a highly complex problem and depends on a number of other factors. Tackling this problem by reducing food waste is not simple and requires a transnational perspective (countries in which a large amount of food is wasted per capita could help by transporting this food to other countries in which the percentage of the population at risk of poverty is higher).

It can also be assumed that food waste does not involve the population at risk of poverty, but only the remainder of the population. Therefore, the relationship between the share of the population at risk of poverty in the total population and the amount of food waste per capita, excluding the population at risk of poverty, was determined, as shown in Figure 6. The value of the Pearson correlation coefficient in this case is -0.032 . 
There is a very weak relationship between these two variables. Thus, in each country, the amount of food waste per capita, excluding the population at risk of poverty, is not related to the percentage of the population at risk of poverty. This may indicate that the presence of people at risk of poverty in individual countries and regions is linked to other factors. However, this does not mean that food waste, particularly in countries with a higher standard of living, does not need to be eliminated. This shows the importance of examining means of reducing food waste in one country (region) that can help tackle poverty in other countries (regions).

Percentage of the population at risk of poverty

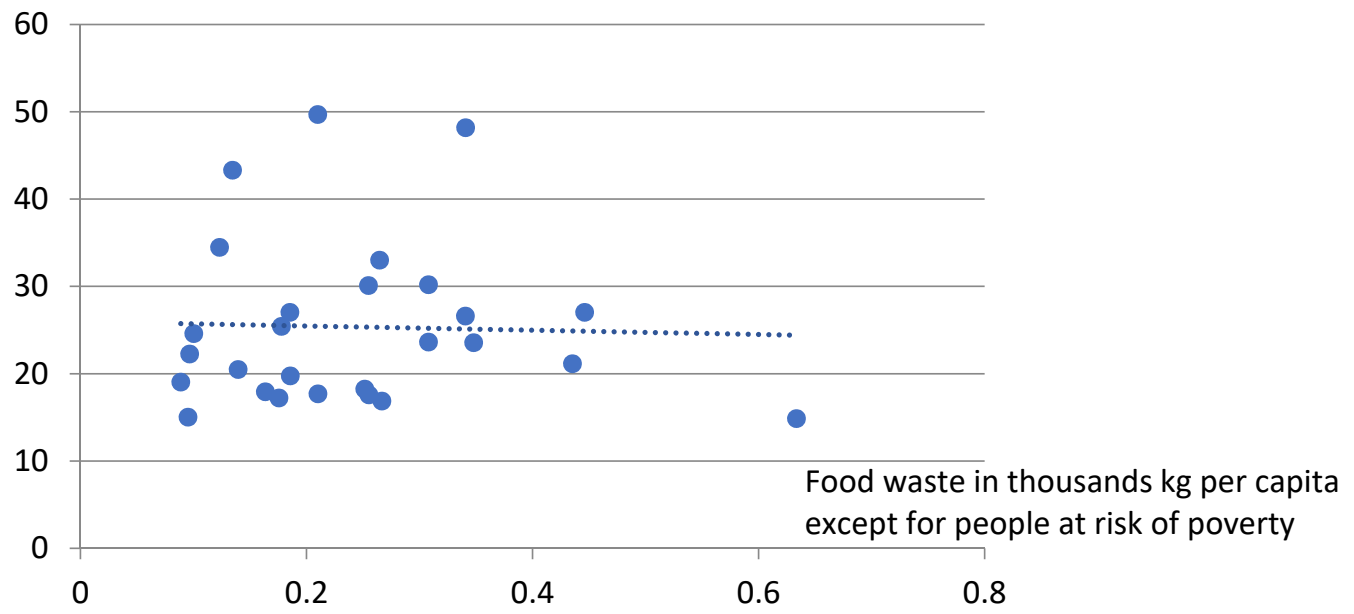

Figure 6. Relationship between the amount of food waste per capita, excluding people at risk of poverty, and the percentage of the population at risk of poverty. Source: created by authors.

Efforts to prevent food waste can also contribute to global poverty reduction. Based on the results above, it can be stated in relation to RQ2 that there is a connection between the amount of food waste and the number of people at risk of poverty; however, because this is an indirect connection, the issue is more complicated.

In addition to the moral, economic, social, and environmental dimensions of the efforts undertaken to prevent food waste, it is important to mention, as an example, a finding of the Dutch bank Rabobank. According to the Champions 12.3 research, $99 \%$ of companies that have invested in food waste prevention have achieved a positive return on investment, and half of the 1200 companies that participated in the research achieved a return on investment of $1400 \%$ or higher. The companies that achieved the highest rate of return were mainly restaurants, hotels, catering companies, and food retailers. These companies recorded revenues ranging from $5 \%$ to $10 \%[67,68]$.

As previously mentioned, 88 million tonnes of food worth EUR 143 billion are thrown away in the EU each year. The countries of the EU should reduce food waste by $30 \%$ before 2020 and by $50 \%$ before 2030. The goal of reducing food waste by half is part of the "Circular Economy Package" presented by the European Commission as a tool for sustainable growth. To make this goal binding on the Member States, it must be passed by the European Parliament and be approved by the Ministers of Environment of all the Member States [69].

Slovakia is lagging regarding the issue of food waste prevention. However, various strategies have been adopted to improve this situation. The Waste Prevention Program of the Slovak Republic for the years 2019-2025, and the Environmental Strategy 2030, address this issue in more detail. An activist from the civic association Free Food (which is involved with addressing the issue of food waste) also notes that this issue is paid less attention than numerous other environmental issues, such as slow fashion, eco design, waste sorting, plastics, biodiversity loss, and deforestation. The problem of food waste simultaneously has ecological, economic, and ethical dimensions, and nearly all people contribute to the 
problem without realizing the impact of this waste [70]. However, the paradox is that a large amount of food is produced in countries in which people do not have enough food for themselves.

\section{Conclusions}

Poverty is caused or exacerbated by numerous factors. The available relevant publications or research sources indicate that poverty can be reduced using appropriate tools. Several possible measures exist to tackle this problem [71,72].

However, the traditional tools are implemented by government bodies in individual countries. In this paper, we noted the possibilities of using managerial and statistical tools. We analyzed poverty and identified potential solutions that could contribute to reducing the problem. By using the managerial tool of Pareto analysis, we discovered the items that account for a large portion of the expenditure of the population. Within European households, food was the third largest $(12,20 \%)$ item of expenditure. Data on the amount of food waste indicated that significant amounts of food are being thrown away across the European Union, and most of this food is still usable. Food belongs to the first group of expenditures of the Pareto analysis (which represents $78.1 \%$ of expenditures). An interesting finding is that only $21.9 \%$ of household expenditure relates to the second group of expenditure items, e.g., furnishings, household equipment, clothing, footwear, health, alcoholic beverages. It follows that this management tool is also relevant and makes a significant contribution to identifying opportunities to tackle the causes of poverty in terms of reducing unnecessary expenditure.

The correlational analysis undertaken in this study was based on three assumptions regarding the EU countries. First, we examined the relationship between the number of populations at risk of poverty and the total amount of food waste per country. Although a relatively strong relationship was found, it was not possible to draw relevant conclusions. To obtain more relevant results, we examined the relationship between the amount of food waste per capita and the proportion of the total population at risk of poverty in a country. In this case, a relatively weak inversely proportional relationship was identified. Finally, we considered the assumption that food waste is not caused by people at risk of poverty. Hence, we examined the relationship between the share of the population at risk of poverty in the total population and the amount of food waste per capita, excluding the population at risk of poverty. A very weak relationship was found. Thus, studies should be undertaken of other factors that are related to the number of populations at risk of poverty. These results show that correlation analysis is also an important and relevant tool, which, unlike Pareto analysis, also reveals the interrelationships between the chosen variables. The selection of variables for the correlation analysis in relation to tackling poverty can be made on a broad basis, which allows for more detailed results.

In this paper, we note the paradox that has arisen, in which food resources are in constant decline while a substantial amount of food is being thrown away, despite increasing expenditure on food by European households. This indicates the potential to improve the use of these resources, in which management also plays a significant role. The information obtained show that poverty reduction can also be addressed via other non-traditional solutions, such as prevention of food waste [73]. Although this solution will not contribute to a significant shift in the poverty rate curve, it has huge significance from moral, environmental, economic, and, in relation to poverty, social perspectives.

In its EU Action Plan, the European Commission [74] set out a harmonized approach for the quantification of food waste. This Action Plan is a tool for the economy that will allow for better prioritization and prevention of food waste. This plan will also allow data to be shared between European countries. The Action Plan will contribute to greater interest in exploring the relationship between energy, food, and water, and will allow measures to be taken to help address global challenges.

The limitations of our research include the potential to examine several factors in addition to those related to the food security of the population. These factors consist of the 
division of individual foods according to importance, in contrast to the current study, in which we examined foods in general. The research sample also represents a limitation. We focused on examining food waste in the European Union, i.e., a collection of developed countries. A focus on developing countries would be likely to achieve different results.

In the future, we would like to focus on examining food security and food waste in developing countries, and compare the results with those of countries of the European Union.

By discussing the characteristics of poverty, its relationships, and potential means of reducing it, this paper contributes to the expansion of the knowledge acquired in previous studies.

Author Contributions: Conceptualization, B.M., J.H., M.F. and P.G.; methodology, J.H.; software, M.F. and J.H.; validation, J.H., M.F. and O.P.; formal analysis, B.B.; investigation, B.M.; resources, A.K.; data curation, M.F.; writing-original draft preparation, J.H., P.G., and O.P.; writing-review and editing, B.M., P.G., B.B. and A.K.; visualization, B.B.; supervision, B.M.; project administration, J.H. and P.G.; funding acquisition, A.K. All authors have read and agreed to the published version of the manuscript.

Funding: This research was funded by the VEGA Project No. 1/0363/20 Economic relations of the share of women in management positions at selected companies in the Slovak Republic.

Institutional Review Board Statement: Not applicable.

Informed Consent Statement: Informed consent was obtained from all subjects involved in the study.

Data Availability Statement: Data are not publicly available, though the data may be made available on request from the corresponding author.

Conflicts of Interest: The authors declare no conflict of interest.

\section{References}

1. Petetin, L. The COVID-19 crisis: An opportunity to integrate food democracy into post-pandemic food systems. Eur. J. Risk Regul. 2020, 11, 326-336. [CrossRef]

2. Batlle-Bayer, L.; Aldaco, R.; Bala, A.; Fullana-i-Palmer, P. Toward sustainable dietary patterns under a water-energy-food nexus life cycle thinking approach. Curr. Opin. Environ. Sci. Health 2020, 13, 61-67. [CrossRef]

3. Chen, C.; Chaudhary, A.; Mathys, A. Nutritional and environmental losses embedded in global food waste. Resour. Conserv. Recycl. 2020, 160, 104912. [CrossRef]

4. Pocol, C.B.; Pinoteau, M.; Amuza, A.; Burlea-Schiopoiu, A.; Glogovețan, A.-I. Food waste behavior among Romanian consumers: A cluster analysis. Sustainability 2020, 12, 9708. [CrossRef]

5. Proctor, K.; Tabatabaie, S.M.H.; Ganti, S.; Murthy, G.S. Gateway to the perspectives of the Food-Energy-Water nexus. Soc. Sci. Total Environ. 2021, 764, 142852. [CrossRef] [PubMed]

6. Sopiah, S.; Kurniawa, D.T.; Nora, E.; Narmaditya, B.S. Does talent management affect employee performance? The moderating role of work engagement. J. Asian Financ. Econ. Bus. 2020, 7, 335-341. [CrossRef]

7. Bulinska-Stangrecka, H.; Bagieńska, A. HR practices for supporting interpersonal trust and its consequences for team collaboration and innovation. Sustainability 2019, 11, 4423. [CrossRef]

8. Repnikova, V.M.; Bykova, O.N.; Skryabin, O.O.; Morkovkin, D.E.; Novak, L.V. Strategic aspects of innovative development of entrepreneurial entities in modern conditions. Int. J. Eng. Adv. Technol. 2019, 8, 32-35.

9. Nikonorova, A.V.; Stroev, P.V.; Morkovkin, D.E.; Bykova, O.N.; Isaichikova, N.I.; Kvak, A.A.; Skryabin, O.O. Development of innovations monitoring system and its implementation in practice of commercial companies. AD ALTA J. Interdiscip. Res. 2019, 9, 233-236.

10. Albrecht, T.R.; Crootof, A.; Scott, C.A. The water-energy-food nexus: A systematic review of methods for nexus assessment. Environ. Res. Lett. 2018, 13, 043002. [CrossRef]

11. Allan, T.; Keulertz, M.; Woertz, E. The water-food-energy nexus: An introduction to nexus concepts and some conceptual and operational problems. Int. J. Water Resour. Dev. 2015, 31, 301-311. [CrossRef]

12. Igaliyeva, L.; Niyazbekova, S.; Serikova, M.; Kenzhegaliyeva, Z.; Mussirov, G.; Zueva, A.; Tyurina, Y.G.; Maisigova, L.A. Towards environmental security via energy efficiency: A case study. Entrepr. Sustain. Issues 2020, 7, 3488-3499. [CrossRef]

13. Nurzhanova, G.; Mussirov, G.; Niyazbekova, S.; Ilyas, A.; Tyurina, Y.G.; Maisigova, L.A.; Troyanskaya, M.; Kunanbayeva, K. Demographic and migration processes of labor potential: A case study the agricultural sector of the Republic of Kazakhstan. Entrep. Sustain. Issues 2020, 8, 656-671. [CrossRef] 
14. Prokopenko, O.; Kornatowski, R. Features of modern strategic market-oriented activity of enterprises. Mark. Manag. Innov. 2018, 1, 295-303. [CrossRef]

15. Campana, P.E.; Zhang, J.; Yao, T.; Andersson, S.; Landelius, T.; Melton, F.; Yan, J. Managing agricultural drought in Sweden using a novel spatially-explicit model from the perspective of water-food-energy nexus. J. Clean. Prod. 2018, 197, 1382-1393. [CrossRef]

16. Prokopenko, O.; Omelyanenko, V. Intellectualization of the phased assessment and use of the potential for internationalizing the activity of clusters of cultural and creative industries of the Baltic Sea regions. Tem J. 2020, 9, 1068-1075. [CrossRef]

17. Moiseev, N.; Mikhaylov, A.; Varyash, I.; Saqib, A. Investigating the relation of GDP per capita and corruption index. Entrepr. Sustain. Issues 2020, 8, 780-794. [CrossRef]

18. Davydenko, V.; Kaźmierczyk, J.; Romashkina, G.F.; Żelichowska, E. Diversity of employee incentives from the perspective of banks employees in Poland-empirical approach. Entrep. Sustain. Issues 2017, 5, 116-126. [CrossRef]

19. Kaźmierczyk, J.; Chinalska, A. Flexible forms of employment, an opportunity or a curse for the modern economy? Case study: Banks in Poland. Entrep. Sustain. Issues Vsi Entrep. Sustain. Cent. 2018, 6, 782-798. [CrossRef]

20. Brandoni, C.; Bosnjakovic, B. Energy, food and water nexus in the European Union: Towards a circular economy. Proc. Inst. Civ. Eng. Energy 2018, 3, 140-144. [CrossRef]

21. Bulinska-Stangrecka, H.; Bagieńska, A. Investigating the links of interpersonal trust in telecommunications companies. Sustainability 2018, 10, 2555. [CrossRef]

22. Jakubowska, D.; Radzymińska, M. Health and environmental attitudes and values in food choices: A comparative study for Poland and Czech Republic. Oeconomia Copernic. 2019, 10, 433-452. [CrossRef]

23. García-Herrero, I.; Margallo, M.; Laso, J.; Batlle-Bayer, L.; Bala, A.; Fullana-i-Palmer, P.; Vazquez-Rowe, I.; Gonzalez, M.J.; Amo-Setien, F.; Durá, M.J.; et al. Nutritional data management of food losses and waste under a life cycle approach: Case study of the Spanish agri-food system. J. Food Compos. Anal. 2019, 82, 103223. [CrossRef]

24. Pelau, C.; Sarbu, R.; Serban, D. Cultural influences on fruit and vegetable food-wasting behavior in the European Union. Sustainability 2020, 12, 9685. [CrossRef]

25. Hoehn, D.; Margallo, M.; Laso, J.; García-Herrero, I.; Bala, A.; Fullana-i-Palmer, P.; Irabien, A.; Aldaco, R. Energy embedded in food loss management and in the production of uneaten food: Seeking a sustainable pathway. Energies 2019, 12, 767. [CrossRef]

26. Jribi, S.; Ben Ismail, H.; Doggui, D.; Debbabi, H. COVID-19 virus outbreak lockdown: What impacts on household food wastage? Environ. Dev. Sustain. 2020, 20, 3939-3955. [CrossRef] [PubMed]

27. Ishangulyyev, R.; Kim, S.; Lee, S.H. Understanding food loss and waste-Why are we losing and wasting food? Foods 2019, 8, 297. [CrossRef] [PubMed]

28. Szczepaniak, I. Comparative advantages in Polish export to the European Union-Food products vs selected groups of non-food products. Oeconomia Copernic. 2018, 9, 287-308. [CrossRef]

29. Šipikalová, S. Globálne Sociálne Nerovnosti: (v Kontexte Krajín Európskej Únie); Vydavatel'stvo EKONÓM: Bratislava, Slovakia, 2013.

30. Marín, D.; Alemán, A.; Montero, P.; Gómez-Guillén, M.C. Encapsulation of food waste compounds in soy phosphatidylcholine liposomes: Effect of freeze-drying, storage stability and functional aptitude. J. Food Eng. 2018, 223, 132-143. [CrossRef]

31. Tavares, G.M.; Croguennec, T.; Carvalho, A.F.; Bouhallab, S. Milk proteins as encapsulation devices and delivery vehicles: Applications and trends. Trends Food Sci. Technol. 2014, 37, 5-20. [CrossRef]

32. Guagnano, G.; Santarelli, E.; Santini, I. Can social capital affect subjective poverty in Europe? an empirical analysis based on a generalized ordered logit model. Soc. Indic. Res. 2016, 128, 881-907. [CrossRef]

33. Nándori, E.S. Subjective poverty and its relation to objective poverty concepts in Hungary. Soc. Indic. Res. 2011, 102, 537-556. [CrossRef]

34. Warshawsky, D.N. The challenge of food waste governance in cities: Case study of consumer perspectives in Los Angeles. Sustainability 2019, 11, 847. [CrossRef]

35. Ravallion, M. Poor, or just feeling poor? On using subjective data in measuring poverty. Policy Res. Work. Papers 2014, 5968, 140-178. [CrossRef]

36. Wulandari, D.; Utomo, S.H.; Narmaditya, B.S.; Kamaludin, M. Nexus between Inflation and Unemployment: Evidence from Indonesia. J. Asian Financ. Econ. Bus. 2019, 6, 269-275. [CrossRef]

37. Spring, C.A.; Biddulph, R. Capturing waste or capturing innovation? Comparing self-organising potentials of surplus food redistribution initiatives to prevent food waste. Sustainability 2020, 12, 4252. [CrossRef]

38. Michelini, L.; Grieco, C.; Ciulli, F.; Di Leo, A. Uncovering the impact of food sharing platform business models: A theory of change approach. Br. Food J. 2020, 122, 1437-1462. [CrossRef]

39. Sen, A. Inequality Reexamined; Harvard University Press: Cambridge, MA, USA, 1992.

40. Sinnathurai, V.; Březinová, O. Poverty incidence and its determinants in the estate sector of Sri Lanka. J. Compet. 2012, 4, 44-55. [CrossRef]

41. OECD. Poverty Reduction, The DAC Guidelines; OECD: Paris, France, 2001; 125p, ISBN 9789264194779. Available online: https: / / www.oecd-ilibrary.org / docserver / 9789264194779-en.pdf?expires=1625553570\&id=id\&accname=guest\&checksum=41 24782AC0A7BA6619DB6348A90D0733 (accessed on 22 May 2021).

42. OECD. DAC Peer Learning Series-COVID-19: Preparing, Learning, Absorbing and Responding; OECD: Paris, France, 2020. Available online: https: / / www.oecd.org/officialdocuments / publicdisplaydocumentpdf/?cote=DCD / DAC(2020)41\&docLanguage=En (accessed on 18 May 2021). 
43. European Commission. Closing the Loop-An. EU Action Plan for the Circular Economy; COM/2015/0614 final; European Commission: Brussels, Belgium, 2020. Available online: https:/ / eur-lex.europa.eu/legal-content/EN/TXT/HTML/?uri=CELEX: 52016DC0763\&rid=4 (accessed on 19 May 2021).

44. Kim, S.; Lee, J. Pyrolysis of food waste over a Pt catalyst in $\mathrm{CO}_{2}$ atmosphere. J. Hazard. Mater. 2020, 393, 122449. [CrossRef]

45. Bhakta Sharma, H.; Panigrahi, S.; Dubey, B.K. Food waste hydrothermal carbonization: Study on the effects of reaction severities, pelletization and framework development using approaches of the circular economy. Bioresour. Technol. 2021, $333,125187$. [CrossRef] [PubMed]

46. Le Borgne, G.; Sirieix, L.; Valette-Florence, P.; Costa, S. Adopting waste-prevention routines: The role of consumer concern for food waste. Appetite 2021, 163, 105188. [CrossRef] [PubMed]

47. Santeramo, F.G. Exploring the link among food loss, waste and food security: What the research should focus on? Agric. Food Secur. 2021, 10, 26. [CrossRef]

48. Liang, Y.; Song, O.; Wu, N.; Li, J.; Zhong, Y.; Zeng, W. Repercussions of COVID-19 pandemic on solid waste generation and management strategies. Front. Environ. Sci. Eng. 2021, 15, 315-325. [CrossRef] [PubMed]

49. Babbitt, C.W.; Babbitt, G.A.; Oehman, J.M. Behavioral impacts on residential food provisioning, use, and waste during the COVID-19 pandemic. Sustain. Prod. Consum. 2021, 28, 315-325. [CrossRef]

50. Park, C.; Choi, H.; Andrew-Lin, K.Y.; Kwon, E.E.; Lee, J. COVID-19 mask waste to energy via thermochemical pathway: Effect of Co-Feeding food waste. Energy 2021, 230, 120876. [CrossRef] [PubMed]

51. Lee, Y.; Kim, S.; Lee, J. Co-pyrolysis for the valorization of food waste and oriental herbal medicine byproduct. J. Anal. Appl. Pyrol. 2021, 154, 105016. [CrossRef]

52. Garcia-Garcia, G.; Woolley, E.; Rahimifard, S.; Colwill, J.; White, R.; Needham, L. A Methodology for sustainable management of food waste. Waste Biomass Valoriz. 2017, 8, 2209-2227. [CrossRef]

53. Elkhalifa, S.; Al-Ansari, T.; Mackey, H.R.; McKay, G. Food waste to biochars through pyrolysis: A review. Resour. Conserv. Recycl. 2019, 144, 310-320. [CrossRef]

54. Dora, M.; Wesana, J.; Gellynck, X.; Seth, N.; Dey, B.; De Steur, H. Importance of sustainable operations in food loss: Evidence from the Belgian food processing industry. Ann. Operat. Res. 2020, 290, 47-72. [CrossRef]

55. Galli, F.; Cavicchi, A.; Brunori, G. Food waste reduction and food poverty alleviation: A system dynamics conceptual model. Agric. Hum. Values 2019, 36, 289-300. [CrossRef]

56. Raja, S. Planning and pandemics COVID 19 illuminates why urban planners should have listened to food advocates all along. Agric. Hum. Values. 2020, 37, 553-554. [CrossRef]

57. Stávková, J.; Birčiaková, N.; Turčínková, J. Material deprivation in selected EU countries according to EU-SILC income statistics. J. Compet. 2012, 4, 145-160. [CrossRef]

58. Halušková, E.; Božik, J. Chudoba: Spoločenské Súvislosti a Sociálne Politiky na jej Odstránenie; IRIS: Bratislava, Slovakia, 2015.

59. Prokopenko, O.V.; Shkola, V.Y.; Domashenko, M.D.; Prokopenko, M.O. Conceptual grounds to form motivational constituent of the international ecological policy. Mark. Manag. Innov. 2015, 4, 245-259. [CrossRef]

60. Redlingshöfer, B.; Barles, S.; Weisz, H. Are waste hierarchies effective in reducing environmental impacts from food waste? A systematic review for OECD countries. Resour. Conserv. Recycl. 2020, 156, 104723. [CrossRef]

61. Eurostat. Household Expenditure by Consumption Purpose-COICOP, EU-28, Share of Total. 2017. Available online: https:/ / ec.europa.eu/eurostat/statistics-explained/images/8/89/Household_expenditure_by_consumption_purpose_-_ COICOP\%2C_EU-28\%2C_2017\%2C_share_of_total.png (accessed on 18 May 2021).

62. Eurostat. Household Expenditure by Consumption Purpose-COICOP, EU-28, Share of Total.png. 2016. Available online: https: / / ec.europa.eu/eurostat/statistics-explained/index.php?title=File:Household_expenditure_by_consumption_purpose_ -_COICOP,_EU-28,_2016,_share_of_total.png\&oldid=370900 (accessed on 18 May 2021).

63. Eurostat. Household Expenditure by Consumption Purpose-COICOP, EU-28, Share of Total. 2018. Available online: https: / / ec.europa.eu/eurostat/statistics-explained/index.php?title=Household_consumption_by_purpose (accessed on 18 May 2021).

64. Eurostat. Final Consumption Expenditure of Households, by Consumption Purpose. \% of Total. 2020. Available online: https: / / ec.europa.eu/eurostat/databrowser/view/tec00134/default/table?lang=en (accessed on 18 May 2021).

65. Snieška, V.; Navickas, V.; Haviernikova, K.; Okreglicka, M.; Gajda, W. Technical Information and Innovation Risks of Industry 4.0 in Small and Medium-sized Enterprises-Case of Slovakia nad Poland. J. Bus. Econ. Manag. 2020, 21, 1269-1284. [CrossRef]

66. Betakova, J.; Haviernikova, K.; Kordos, M.; Lajcin, D. Factors Affecting the Decision of SMEs' to Be Involved in Cluster Cooperation. Ekon. Časopis 2021, 69, 257-277. [CrossRef]

67. Gustavsson, J.; Cederberg, C.; Sonesson, U.; van Otterdijk, R.; Meybeck, A. Global Food Losses and Food Waste. Extent, Causes and Prevention; Food and Agriculture Organization of the United Nations: Rome, Italy, 2011.

68. Janssen, T.; Van de Hei, L. From food waste to future value. Econ. Rep. 2018. Available online: https://economics.rabobank.com/ publications /2018/march/from-food-waste-to-future-value/ (accessed on 22 May 2021).

69. Pokorná, V. Európa Má Vyhadzovat' o Polovicu Menej Potravín. Má to Však Jeden Háčik. 2017. Available online: https: //hnonline.sk/svet/952212-europa-ma-vyhadzovat-o-polovicu-menej-potravin-ma-to-vsak-jeden-hacik (accessed on 22 May 2021). 
70. Marcišiak, M. Plytvajú Potravinami Najviac Obchody? Ani Náhodou. Budete Prekvapení, Kto je Najväčší „Škodca“. 2019. Available online: https://www.tvnoviny.sk/exkluzivne/1974040_plytvaju-potravinami-najviac-obchody-ani-nahodou-budeteprekvapeni-kto-je-najvacsi-skodca (accessed on 22 May 2021).

71. Varyash Varyash, I.; Mikhaylov, A.; Moiseev, N.; Aleshin, K. Triple bottom line and corporate social responsibility performance indicators for russian companies. Entrep. Sustain. Issues 2020, 8, 313-329. [CrossRef]

72. Gruenbichler, R.; Klucka, J.; Haviernikova, K.; Strelcova, S. Business Performance Management in Small and Medium-Sized Enterprises in the Slovak Republic: An Integrated Three- Phase-Framework for Implementation. J. Compet. 2021, 13, 42-58. [CrossRef]

73. Orgonáš, J.; Paholková, B.; Drábik, P. Franchising modern form of business for small and medium sized enterprises in the 21st. century. Manag. Stud. 2020, 8, 69-73.

74. European Commission. Organic Action Plan; European Commission: Brussels, Belgium, 2020. Available online: https://ec.europa. eu/info/food-farming-fisheries/farming/organic-farming/organic-action-plan_en (accessed on 19 May 2021). 